\title{
PENGARUH PEMBERIAN NASI BERAS MERAH (Oryza nivara) DAN NASI BERAS HITAM (Oryza sativa L.indica) TERHADAP KADAR hsCRP TIKUS WISTAR (Rattus norvegicus) DIABETES MELITUS TIPE 2
}

\author{
Golda Sharon Sitanggang ${ }^{1}$, Martha Ardiaria ${ }^{1}$, Ayu Rahadiyanti ${ }^{1}$ \\ ${ }^{1}$ Departemen Ilmu Gizi, Fakultas Kedokteran, Universitas Diponegoro \\ Jln. Prof. H. Soedarto, SH., Semarang, Telp (024) 76402881, Email : gizifk@undip.ac.id
}

\begin{abstract}
Background: Diabetes mellitus (DM) is a chronic disease caused by insulin deficiency or insulin resistance characterized by hiperglicemia or high glucose concentration in the blood. hsCRP is the most sensitive measurement method of inflammatory marker level. Red rice and black rice are known as high level of anthocyanin and fiber that potentially increase insulin sensitivity and decrease inflamation.

Objective: Determine the difference of hsCRP level between red rice and black rice intervensions in diabetic rats Methods: It was true experimental with post test control design in 24 Rattus norvegicus male, 6 samples maintained healthy in the negative control group $(\mathrm{K}-)$ and 18 samples were injected STZ $(50 \mathrm{mg} / \mathrm{kg}$ body weight) and $\mathrm{NA}(110 \mathrm{mg} / \mathrm{kg}$ body weight) to become Type 2 DM. Diabetic samples divided into 3 groups: positive control group $(K+)$, red rice intervention (P1), and black rice intervention (P2). The intervention was given for 28 days. After the intervention, hsCRP was measured. hsCRP levels analyzed using ELISA method. Statistical analysis using ANOVA and Duncan post hoc test. Result: There were significant differences in hsCRP levels $(p=0.000)$. P1 group had hsCRP level $18.8 \pm 0.50 \mathrm{ng} / \mathrm{ml}$ and $P 2$ group had hsCRP level $16.3 \pm 0.72 \mathrm{ng} / \mathrm{ml}$

Conclusion: Red rice and black rice show significant differences in hsCRP levels. hsCRP levels were lower in the rat group with black rice than others.
\end{abstract}

Keyword: Red rice, black rice, type 2 diabetes mellitus, hsCRP

\begin{abstract}
ABSTRAK
Latar belakang: Diabetes Melitus (DM) merupakan penyakit kronik yang disebabkan defisiensi atau resistensi insulin, yang ditandai tingginya konsentrasi glukosa dalam darah. Kadar hsCRP dapat digunakan untuk melihat marker inflamasi yang paling sensitif pada diabetesi. Beras merah dan beras hitam diketahui kaya akan antosianin dan serat yang berpotensi meningkatkan sensitivitas insulin dan mengurangi inflamasi.

Tujuan: Mengetahui perbedaan pemberian nasi beras merah dan nasi beras hitam terhadap kadar hsCRP pada tikus wistar DM Tipe 2

Metode: Jenis penelitian ini adalah true experimental dengan post test control group design. Besar sampel penelitian 24 ekor tikus wistar jantan, 6 ekor dikondisikan sehat yaitu kelompok $K(-)$ dan 18 ekor tikus dikondisikan DM dengan injeksi STZ $50 \mathrm{mg} / \mathrm{kg}$ BB dan $110 \mathrm{NA} \mathrm{mg/kg} \mathrm{BB.} \mathrm{Kemudian} \mathrm{tikus} \mathrm{DM} \mathrm{dibagi} \mathrm{menjadi} 3$ kelompok yaitu kelompok $K(+)$, kelompok perlakuan nasi beras merah (P1) dan kelompok perlakuan nasi beras hitam (P2). Intervensi dilakukan selama 28 hari, kadar hsCRP diukur menggunakan metode ELISA. Analisis statistik menggunakan uji ANOVA dan dilanjutkan dengan uji post hoc Duncan.

Hasil: Terdapat perbedaan signifikan kadar hsCRP antar kelompok $(p=0,000)$. Kelompok P1 memiliki kadar hsCRP

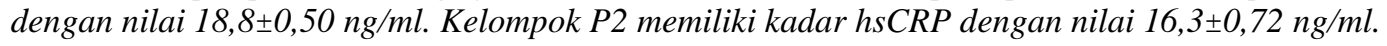

Simpulan: Pemberian nasi beras merah dan nasi beras hitam menunjukkan adanya perbedaan kadar hsCRP secara signifikan. Kadar hsCRP lebih rendah pada kelompok tikus dengan pemberian nasi beras hitam.
\end{abstract}

Kata kunci: Beras merah, beras hitam, diabetes melitus tipe 2, hsCRP

\section{PENDAHULUAN}

Diabetes Melitus (DM) merupakan suatu penyakit kronik yang disebabkan defisiensi atau tidak diproduksinya hormon insulin oleh pankreas atau resistensi insulin, sehingga menyebabkan meningkatnya konsentrasi glukosa dalam darah yang disertai dengan gangguan metabolisme lemak dan protein. Keadaan hiperglikemia pada penderita DM dapat memicu kerusakan pada sistem dalam tubuh khususnya pembuluh darah dan saraf. ${ }^{1,2}$ Pasien yang mengalami DM berisiko tinggi untuk menderita berbagai penyakit seperti aterosklerosis, penyakit kardiovaskular, stroke, hipertensi, kebutaan, amputasi, penyakit periodontal dan penyakit ginjal. ${ }^{3,4}$ Orang dewasa yang memiliki riwayat diabetes memiliki resiko kematian yang lebih cepat sebanyak 2 hingga 4 kali karena penyakit kardiovaskuler dibandingkan dengan orang dewasa yang tidak memiliki riwayat $\mathrm{DM}^{4}{ }^{4}$ Penyakit kardiovaskuler merupakan penyebab utama morbiditas dan 
mortalitas pada DM. ${ }^{5}$ Hal ini disebabkan keadaan hiperglikemia yang memicu Reactive Oxygen Species (ROS) dan Advance Glycation End Products (AGEs) ${ }^{6}$ yang menyebabkan peningkatan radikal bebas sehingga menimbulkan stress oksidatif yaitu keadaan dimana antioksidan tubuh tidak dapat menekan radikal bebas dan memicu inflamasi di dalam tubuh. ${ }^{6,7,8}$

Beras merupakan bahan makanan yang paling banyak dikonsumsi di Indonesia dibandingkan dengan bahan pangan lainnya. Ada beberapa jenis beras yang terdapat di Indonesia yaitu beras putih, beras merah dan beras hitam. ${ }^{9}$ Warna yang terdapat pada beras merah dan beras hitam ini disebabkan adanya antosianin. ${ }^{10,11}$ Antosianin adalah senyawa yang menyebabkan timbulnya warna merah, biru, ungu pada padi, buah, sayur, dan produk hortikultura lainnya. ${ }^{12}$ Kadar antosianin yang tinggi menyebabkan warna menjadi semakin gelap pada suatu bahan pangan. ${ }^{13}$

Antosianin termasuk komponen flavonoid, yaitu turunan polifenol yang memiliki kemampuan antioksidan, antikanker, antiinflamasi, antiatherogenik dan antioksidan. ${ }^{14,15}$ Antosianin sebagai antioksidan dinilai mampu sebagai treatment dan baik dalam pencegahan penyakit dengan inflamasi kronik. Penelitian menunjukkan bahwa beras merah dan beras hitam efektif dalam melawan inflamasi. ${ }^{16}$ Antosianin di dalam beras merah dan beras hitam juga dapat mengurangi inflamasi dan menurunkan histamin yang berperan sebagai trigger inflamasi dan menurunkan kadar faktor inflamasi (IL6 dan TNF $\alpha$ ) pemicu $C$-Reactive Protein (CRP). ${ }^{16,17}$

Beras merah dan beras hitam juga memiliki nilai serat yang lebih tinggi dibandingkan beras putih. ${ }^{18}$ Konsumsi serat yang cukup, dapat menimbulkan efek hipoglikemik karena memiliki kemampuan dalam memperlambat pengosongan lambung, mengubah peristaltik lambung, memperlambat difusi glukosa, menurunkan aktifitas amilase akibat meningkatnya viskositas isi usus, serta menurunkan waktu transit yang mengakibatkan pendeknya absorbsi glukosa dan berpengaruh terhadap peningkatan sekresi. ${ }^{19}$

Karbohidrat merupakan salah satu zat gizi makro yang berperan penting pada diabetesi, dimana jenis karbohidrat tersebut mempengaruhi perjalanan penyakit DM. ${ }^{20}$ Parameter yang dapat digunakan untuk mengelompokkan pangan berdasarkan pengaruh fisiologisnya terhadap respon kadar glukosa darah setelah pangan dikonsumsi adalah Indeks Glikemik (IG). ${ }^{21}$ Semakin tinggi IG pangan, semakin cepat pula kemampuannya untuk menaikkan kadar glukosa darah. ${ }^{22}$ Jenis beras merah dan beras hitam memiliki nilai Indeks Glikemik (IG) yang rendah dibandingkan dengan beras putih. Konsumsi makanan dengan indeks glikemik rendah dapat mengontrol kadar glukosa darah penderita DM dan meningkatkan sensitivitas insulin dan mengurangi resiko terjadinya komplikasi. ${ }^{23}$

CRP merupakan senyawa yang berperan secara langsung dalam proses inflamasi. CRP dapat digunakan untuk memeriksa ada atau tidaknya inflamasi dalam tubuh. ${ }^{24}$ Sesuai namanya, High Sensitive C-Reactive Protein (hsCRP) memiliki sensitivitas yang lebih tinggi daripada pengukuran CRP. ${ }^{25}$

Penelitian mengenai pengaruh pemberian nasi beras merah dan nasi beras hitam terhadap kadar $h s$ CRP belum pernah dilakukan sebelumnya. Maka perlu dilakukan penelitian untuk mengetahui efektivitas mengenai nasi beras merah dan nasi beras hitam secara in vivo terhadap kadar $h s$ CRP pada tikus wistar diabetes melitus tipe 2 .

\section{METODE}

Jenis penelitian ini adalah true experimental dengan rancangan post test control group. Penelitian dan pengumpulan data dilakukan April - Mei 2018. Pembuatan produk nasi beras merah maupun nasi beras hitam,penelitian uji in vivo, serta analisis hasil kadar hsCRP dilaksanakan di Laboratorium Pusat Studi Pangan dan Gizi Universitas Gadjah Mada (UGM) Yogyakarta. Subjek penelitian yaitu tikus jantan galur wistar (Rattus norvegicus). Kriteria inklusi yang digunakan adalah tikus wistar jantan, berusia 2 bulan, berat badan 175-200 gram, kondisi sehat (gerakan aktif dan tidak cacat). Kriteria eksklusi yaitu tikus tidak bergerak secara aktif saat tidak sedang tidur, tikus mengalami penurunan berat badan hingga kurang dari 100 gram, mengalami perubahan perilaku (sakit dan kehilangan nafsu makan) dan tikus mati saat penelitian berlangsung.

Penentuan besar subjek minimal menurut World Health Organization (WHO) yaitu dengan jumlah sampel minimal 5 ekor hewan coba pada tiap kelompok ditambah 1 ekor dari batas minimal sehingga dibutuhkan 24 ekor tikus pada penelitian ini. Sejumlah 6 tikus dalam kondisi normal dikelompokkan menjadi kontrol negatif (K(-)) dan 18 tikus dikondisikan mengalami Diabetes Melitus (DM) yang selanjutnya dikelompokkan menjadi kelompok kontrol positif $(\mathrm{K}(+))$, Perlakuan 1 (P1), Perlakuan $2(\mathrm{P} 2)$ berdasarkan metode simple random sampling. Pengkondisian DM apabila kadar Glukosa Darah Puasa (GDP) tikus > $200 \mathrm{mg} / \mathrm{dL}$. Pada penelitian kelompok $\mathrm{K}(-)$ dan $\mathrm{K}(+)$ tidak diberikan intervensi, sedangkan kelompok P1 diberikan nasi beras merah dan kelompok P2 diberikan nasi beras hitam. Variabel bebas di dalam penelitian ini adalah pemberian nasi beras merah dan nasi beras hitam. Variabel terikat dalam penelitian ini adalah kadar 
hsCRP. Variabel terkontrol yaitu galur tikus, umur, jenis kelamin, pakan, kandang dan berat badan hewan coba.

Dosis pemberian didasarkan pada Angka Kecukupan Gizi yang dianjurkan bagi orang Indonesia bahwa kebutuhan serat dan karbohirat harian laki-laki dewasa dengan berat badan $60 \mathrm{~kg}$ dan aktifitas sedang adalah $25 \mathrm{~g} /$ hari dan 375 g/hari. ${ }^{26}$ Kebutuhan antosianin untuk membantu menurunkan dislipidemia, resistensi insulin dan meningkatkan aktivitas antioksidan di dalam tubuh adalah 320 mg/hari. ${ }^{27}$ Hasil perhitungan dosis kemudian dikonversikan dengan dosis untuk tikus dengan berat badan 200 gram. Berdasarkan hasil perhitungan yang telah dilakukan, diketahui bahwa banyaknya beras merah yang diperlukan untuk mencukupi kebutuhan antosianin, serat dan karbohidrat sebanyak 15,2 gram/hari, sementara hasil perhitungan untuk beras hitam adalah 14,8 gram/hari.

Saat perlakuan, tikus diberikan pakan sebanyak 20 gram yaitu pada kelompok tikus P1 15,2 gram nasi beras merah ditambah 4,8 gram pakan standar, sedangkan pada kelompok tikus P2 diberikan 14,8 gram nasi beras hitam ditambah 5,2 gram pakan standar, serta 20 gram pakan standar untuk kelompok $\mathrm{K}(-)$ dan $\mathrm{K}(+)$. Pakan standar yang digunakan adalah COMFEED AD II. COMFEED AD II mengandung karbohidrat $51 \%$, protein kasar $15 \%$, lemak kasar $7 \%$ dan serat kasar 6\%.

Penelitian diawali dengan pembuatan pakan untuk kelompok perlakuan terlebih dahulu. Beras merah dan beras hitam terlebih dahulu dimasak hingga menjadi nasi. Setelah nasi masak, nasi kemudian dicampur dan dihomogenkan dengan pakan standar COMFEED AD II dengan jumlah nasi beras merah dan pakan standar sebesar 15,2 gram dan 4,8 gram serta jumlah nasi beras hitam dan pakan standar sebesar 14,8 gram dan 5,2 gram. Setelah dicampur, pakan kemudian dicetak hingga menjadi pelet. Proses homogenisasi dan pencetakan pakan menggunakan mesin ekstruder. Pakan kemudian dikeringkan dengan suhu rendah $\pm 40^{\circ} \mathrm{C}$ selama 8 jam menggunakan cabin dryer.

Tikus sebanyak 24 ekor diaklimatisasi selama 7 hari dengan diberi pakan standar dan minum aquades ad libitum. Pasca adaptasi 7 hari, sampel diinjeksi streptozotocin (STZ) $50 \mathrm{mg} / \mathrm{kg} \mathrm{BB}$ dan nicotinamid (NA) $110 \mathrm{mg} / \mathrm{kg}$ BB untuk kelompok kontrol positif dan kelompok perlakuan untuk membuat tikus DM sementara kelompok kontrol negatif tidak diinjeksi STZ dan NA. Hari ke 3 pasca injeksi STZ-NA dilakukan pemeriksaan glukosa darah dan tikus. Tikus dinyatakan DM jika kadar glukosa darah 200-300 mg/dl. Setelah tikus dinyatakan DM, diberikan intervensi nasi beras merah pada kelompok P1 dan nasi beras hitam pada kelompok P2.

Data yang dikumpulkan berupa berat badan tikus yang diukur setiap 7 hari sekali dimulai sejak sehari sebelum pemberian intervensi. Setelah 28 hari masa intervensi, selanjutnya dilakukan pemeriksaan kadar $h s$ CRP menggunakan metode Enzym-Linked Immunosorbent Assay (ELISA). Penelitian ini telah memperoleh ethical clearance dari Komisi Etik Penelitian Kesehatan (KEPK) Fakultas Kedokteran Universitas Diponegoro/Rumah Sakit Umum Pusat Dr. Kariadi No.15/EC/H/FK-RSDK/IV/2018. Uji normalitas data menggunakan uji Saphiro Wilks, kemudian dianalisis dengan uji ANOVA dan dilanjutkan uji post hoc Duncan.

\section{HASIL \\ Karakteristik Subjek}

Berdasarkan Tabel 1, diketahui bahwa kelompok K(-) memiliki kadar glukosa darah puasa pada rentang normal. Pada kelompok $\mathrm{K}(+)$, P1 dan $\mathrm{P} 2$, tikus telah mengalami DM. Berdasarkan uji post hoc Duncan yang telah dilakukan, tidak terdapat perbedaan GDP yang signifikan antara kelompok P1 dan $\mathrm{P} 2$ namun terdapat perbedaan pada kelompok K() dan $\mathrm{K}(+)$. Berat badan pada kelompok K (-) memiliki perbedaan yang signifikan dibanding kelompok $\mathrm{K}(+), \mathrm{P} 1$ dan P2.

Tabel 1. Tabel Karakteristik Subjek 3 Hari Pasca Injeksi STZ dan NA

\begin{tabular}{lcc}
\hline Kelompok & GDP $(\mathbf{m g} / \mathbf{d l})$ & $\begin{array}{c}\text { Berat Badan (g) } \\
\text { Rerata } \pm \text { SB }\end{array}$ \\
\hline $\mathrm{K}(-)$ & $68,7 \pm 2,41^{\mathrm{a}}$ & $193,8 \pm 2,93^{\mathrm{a}}$ \\
$\mathrm{K}(+)$ & $259,8 \pm 3,09^{\mathrm{b}}$ & $186,2 \pm 5,15^{\mathrm{b}}$ \\
$\mathrm{P} 1$ & $268,4 \pm 6,19^{\mathrm{b}, \mathrm{c}}$ & $185,8 \pm 3,49^{\mathrm{b}}$ \\
$\mathrm{P} 2$ & $264,1 \pm 5,24^{\mathrm{c}}$ & $184,5 \pm 3,02^{\mathrm{b}}$ \\
$p^{*}$ & 0,000 & 0,001 \\
\hline$*:$ uji One Way ANOVA & & \\
a,b,c) : notasi yang berbeda pada kolom yang sama menunjukkan perbedaan yang bermakna pada uji Duncan
\end{tabular}

\section{Rerata Berat Badan Tikus}

Berdasarkan tabel 2, diketahui terdapat peningkatan berat badan secara signifikan pada kelompok K(-), P1 dan P2 sementara pada kelompok $\mathrm{K}(+)$ mengalami penurunan yang signifikan. Perubahan berat badan yang terbesar dialami oleh 
kelompok $\mathrm{K}(-)$ yaitu terjadi peningkatan sebesar $14,81 \%$. Setelah dilakukan uji ANOVA, terdapat perbedaan $\mathrm{BB}$ yang signifikan antar kelompok pre dan post intervensi serta pada delta perubahan berat badan. Perbedaan yang signifikan saat pre intervensi terdapat pada kelompok K(-), sedangkan pada saat post intervensi dan delta perubahan berat badan terdapat perbedaan yang signifikan pada kelompok $\mathrm{K}(-)$ dan $\mathrm{K}(+)$.

Tabel 2. Rerata Perubahan Berat Badan Sebelum dan Sesudah Pemberian Intervensi

\begin{tabular}{|c|c|c|c|c|c|}
\hline Kelompok & $\begin{array}{c}\text { Sebelum } \\
\text { Rerata } \pm \text { SB }\end{array}$ & $\begin{array}{c}\text { Sesudah } \\
\text { Rerata } \pm \text { SB }\end{array}$ & $p^{* *}$ & $\begin{array}{c}\Delta \text { perubahan } \\
\text { Rerata } \pm \text { SB }\end{array}$ & $\%$ \\
\hline $\mathrm{K}(-)$ & $193,8 \pm 2,93^{\mathrm{a}}$ & $222,5 \pm 2,88^{\mathrm{a}}$ & 0,000 & $28,7 \pm 2,93^{\mathrm{a}}$ & 14,81 \\
\hline $\mathrm{K}(+)$ & $186,2 \pm 5,15^{\mathrm{b}}$ & $171,5 \pm 4,59^{b}$ & 0,000 & $-14,7 \pm 1,21^{b}$ & 7,89 \\
\hline $\mathrm{P} 1$ & $185,8 \pm 3,49^{b}$ & $202,8 \pm 2,79^{c}$ & 0,000 & $17,0 \pm 0,89^{c}$ & 9,15 \\
\hline $\mathrm{P} 2$ & $184,5 \pm 3,02^{\mathrm{b}}$ & $201,3 \pm 2,50^{\mathrm{c}}$ & 0,000 & $16,8 \pm 0,75^{\mathrm{c}}$ & 9,11 \\
\hline$p^{*}$ & 0,001 & 0,000 & & 0,000 & \\
\hline
\end{tabular}

*: uji one way ANOVA; ${ }^{* *}$ : uji paired t test; ${ }^{\mathrm{a}, \mathrm{b}, \mathrm{c})}$ : notasi yang berbeda pada kolom yang sama menunjukkan perbedaan yang bermakna pada uji Duncan

\section{Kadar hsCRP Setelah Intervensi Pakan}

Berdasarkan tabel 3, diketahui adanya perbedaan yang signifikan terhadap kadar $h s C R P$ post antar kelompok tikus. Kelompok $\mathrm{K}(+)$ merupakan kelompok dengan kadar $h s$ CRP yang paling tinggi dibanding kelompok lainnya. Kelompok $\mathrm{K}(-)$ merupakan kelompok dengan kadar $h s \mathrm{CRP}$ terendah. Berdasarkan uji Duncan yang telah dilakukan, diketahui bahwa terdapat perbedaan yang signifikan antar semua kelompok.

Tabel 3. Tabel Kadar hsCRP Setelah Intervensi Pakan

\begin{tabular}{lcc}
\hline Kelompok & $\begin{array}{c}\text { Kadar } \boldsymbol{h} \boldsymbol{s C R P}(\mathbf{n g} / \mathbf{m l}) \\
\text { Rerata } \pm \text { SB }\end{array}$ & $\boldsymbol{p}^{*}$ \\
\hline $\mathrm{K}(-)$ & $13,7 \pm 0,49^{\mathrm{a}}$ & 0,000 \\
$\mathrm{~K}(+)$ & $24,3 \pm 0,84^{\mathrm{b}}$ & \\
$\mathrm{P} 1$ & $18,8 \pm 0,50^{\mathrm{c}}$ & \\
$\mathrm{P} 2$ & $16,3 \pm 0,72^{\mathrm{d}}$ & \\
\hline
\end{tabular}

*: Uji one way ANOVA; ${ }^{\mathrm{a}, \mathrm{b}, \mathrm{c}, \mathrm{d})}$ notasi yang berbeda pada kolom yang sama menunjukkan perbedaan yang bermakna pada uji Duncan

\section{PEMBAHASAN}

Penelitian ini menggunakan tikus wistar yang telah dikondisikan mengalami DM dengan injeksi 50 $\mathrm{mg} / \mathrm{kgBB}$ STZ dan $110 \mathrm{mg} / \mathrm{kgBB}$ NA. Kelompok tikus $\mathrm{K}(+), \mathrm{P} 1$ dan $\mathrm{P} 2$ telah mengalami DM. Hal ini terjadi karena adanya reaksi akibat STZ dan NA yang menyebabkan kerusakan oksidatif di dalam tubuh. ${ }^{28}$ Penggunaan STZ mampu mempertahankan keadaan hiperglikemia pada tikus dalam waktu yang lama. Reaksi STZ terhadap sel- $\beta$ pankreas disertai dengan perubahan karakteristik pada insulin darah dan konsentrasi glukosa yang meyebabkan hiperglikemia dan menurunnya level insulin dalam darah. STZ mempengaruhi oksidasi glukosa dan menurunkan biosintesis dan sekresi insulin. STZ masuk ke sel- $\beta$ pankreas melalui transporter glukosa Glucose Transporter 2 (GLUT2) dan menyebabkan menurunnya ekskresi dari GLUT2. Hal ini mengakibatkan menurunnya sensitifitas reseptor insulin perifer sehingga berdampak pada meningkatnya resistensi insulin dan meningkatkan kadar glukosa darah. ${ }^{29}$ Tikus juga diinjeksi dengan NA yang mampu melindungi sel $\beta$-pankreas secara parsial untuk mencegah kerusakan sel $\beta$-pankreas secara keseluruhan. ${ }^{30}$

Berdasarkan tabel 1, setelah dilakukan uji ANOVA dan post hoc Duncan terdapat perbedaan yang signifikan pada kadar GDP subjek. Kelompok tikus $\mathrm{K}(-)$ memiliki kadar GDP yang paling rendah karena pada kelompok tersebut subjek tidak diinjeksi STZ dan NA. Kelompok tikus $\mathrm{K}(+)$ menunjukkan perbedaan yang signifikan secara statistik, namun tidak memiliki perbedaan yang signifikan secara klinis karena tikus telah mengalami DM.

Berdasarkan tabel 2, terdapat perbedaan berat badan yang signifikan pada kelompok $\mathrm{K}(-)$ sebelum intervensi. Hal ini terjadi karena kelompok tikus K(-) tidak dikondisikan DM sedangkan kelompok tikus $\mathrm{K}(+)$, P1 dan P2 mengalami resistensi insulin dimana tubuh tidak mampu menyerap glukosa yang ada di dalam darah. Pada penderita DM, glukosa yang masuk ke tubuh tidak dapat dibentuk dan digunakan menjadi energi sehingga ketidaksediaan glukosa dalam sel mengakibatkan terjadinya glikogenolisis secara berlebihan. Glikogenolisis adalah pemecahan glikogen yang terdapat pada hati dan otot untuk digunakan menjadi energi sedangkan glukosa yang diasup kelompok DM dan berada di darah kemudian akan terbuang sebagian melalui urin. Terjadinya glikogenolisis yang terus menerus menyebabkan terjadi pengurangan jumlah jaringan otot. Penderita akan kehilangan berat tubuh namun terdapat polifagia dimana terjadi perangsangan pusat nafsu makan di hipotalamus akibat kurangnya pemakaian glukosa di sel, jaringan dan hati. ${ }^{31}$ Disamping itu asupan kalori tetap normal. ${ }^{32}$ 
Selain glikogenolisis, ketidaksediaan glukosa akan mengakibatkan glukoneogenesis. Glukoneogenesis adalah pembentukan glukosa dari senyawa lain yaitu lemak dan protein. Glukoneogenesis akan menggunakan lemak terlebih dahulu daripada protein. Lipid terpecah menjadi komponen penyusunnya yaitu asam lemak dan gliserol. Asam lemak dimobilisasi dari cadangan jaringan adiposa dan dioksidasi dalam hati menjadi asetil-KoA. Selanjutnya asetil KoA masuk dalam siklus Krebs dan kemudian akan dibentuk menjadi energi. Sementara itu gliserol masuk dalam jalur glikolisis. ${ }^{31}$

Proses glukoneogenesis yang berlebihan pada tikus DM menyebabkan sel-sel hati akan meningkatkan produksi glukosa dari substrat selain lipid, yaitu dengan merombak protein. Asam amino hasil perombakan ditransaminasi sehingga dapat menghasilkan substrat dalam pembentukan glukosa. Peristiwa berlangsung secara terus menerus dikarenakan insulin yang membatasi glukoneogenesis sangat sedikit atau tidak ada sama sekali. Glukosa yang dihasilkan kemudian akan terbuang melalui urin dan mengakibatkan terjadi pengurangan jumlah jaringan otot dan jaringan adiposa secara signifikan. Hal tersebut memicu diabetesi kehilangan berat badan. ${ }^{31}$

Berdasarkan tabel 2, berat badan kelompok tikus setelah intervensi memiliki perbedaan yang signifikan. Tabel menunjukkan kelompok tikus $\mathrm{K}(+)$ mengalami penurunan berat badan yang signifikan. Hal ini masih terkait dengan keadaan glikogenolisis dan glukoneogenesis yang terjadi secara terus menerus karena glukosa yang diasup tidak dapat digunakan menjadi energi di dalam tubuh.

Setelah dilakukan intervensi selama 28 hari, terdapat perbedaan $h s \mathrm{CRP}$ yang signifikan antar kelompok. Berdasarkan tabel 3, tikus kelompok K(-) menunjukkan kadar hsCRP yang paling rendah dibandingkan kelompok lain. Hal ini disebabkan tikus dalam keadaan sehat dan tidak dikondisikan DM, sehingga tidak terjadi hiperglikemia yang memicu proses inflamasi di dalam tubuh kelompok tikus K(-).

Data kelompok tikus $\mathrm{K}(+)$ yang dikondisikan DM, menunjukkan kadar $h s$ CRP yang paling tinggi daripada kelompok yang lain. Hal ini menunjukkan pengkondisian DM pada tikus memicu inflamasi dan menyebabkan meningkatnya kadar $h s \mathrm{CRP}$.

Hiperglikemia dapat meningkatkan akumulasi ROS dengan merusak mikrovaskular. Kadar glukosa yang tinggi juga menyebabkan glukosa dapat berinteraksi secara nonenzimatis dengan gugus amino protein sehingga membentuk produk Advance Glycation End (AGE). Adanya AGE tersebut menyebabkan pelepasan berbagai sitokin yang dapat mempengaruhi proliferasi dan fungsi sel vaskular dan meningkatkan akumulasi ROS. Peningkatan ROS menyebabkan sel menjadi rusak karena ROS mengambil elektron yang terdapat pada sel. Hal tersebut menyebabkan sel akan mengalami kerusakan dan mengeluarkan elektron bebas yang reaktif dan memicu diproduksinya sitokin pro inflamasi seperti Tumor Necrosis Factors (TNF- $\alpha$ dan TNF- $\beta$ ), interleukin (IL 6) dan interferon- $\gamma$ serta menimbulkan peningkatan kadar $h s C R P$ yang menandakan adanya inflamasi di dalam tubuh. ${ }^{24,33}$

Kelompok P1 dan P2 memiliki kadar $h s \mathrm{CRP}$ yang lebih rendah daripada kelompok $\mathrm{K}(+)$. Rendahnya kadar $h s$ CRP pada kelompok tikus P1 dan P2 dibandingkan kelompok tikus tanpa perlakuan, menandakan terjadinya pengurangan peradangan dan penurunan keparahan penyakit pada penderita diabetes melitus.

Pakan rendah Indeks Glikemik (IG) yang diberikan pada kelompok tikus P1 dan P2 mengakibatkan kenaikan glukosa terjadi sangat lambat dan akan dicerna serta diubah menjadi glukosa secara perlahan-lahan. Proses yang lambat menyebabkan puncak kadar glukosa darah juga akan rendah dan fluktuasi peningkatan kadar gula relatif pendek. ${ }^{34}$

Selain itu, pakan yang mengandung tinggi serat tidak larut hemiselulosa ${ }^{35}$ juga dapat mencegah hiperglikemia dimana serat akan berubah menjadi gel dan mengikat serta memperlambat penyerapan glukosa. ${ }^{34,36}$ Lambatnya penyerapan glukosa menyebabkan produksi asam lemak bebas menurun, rangsangan sekresi hormon kontrainsulin (glukagon, steroid, hormon pertumbuhan dan katekolamin) juga menurun, sehingga mengurangi hiperglikemia. ${ }^{37}$ Serat juga akan mencegah autooksidasi glukosa di dalam darah sehingga dapat mengurangi produksi radikal bebas di dalam tubuh., ${ }^{8,36,38}$ Hal ini mempengaruhi kadar $h s \mathrm{CRP}$ pada kelompok P1 dan $\mathrm{P} 2$, dimana pakan tinggi serat dapat membantu mengontrol glukosa darah dan membantu mengurangi autooksidasi sehingga tidak terjadi hiperglikemia yang memicu radikal bebas atau inflamasi. ${ }^{8,31}$

Selain IG yang rendah dan kandungan serat yang tinggi, pakan kelompok tikus P1 dan P2 juga mengandung antosianin yang berasal dari pigmen beras merah dan beras hitam. Kadar antosianin dalam pakan intervensi memiliki peran penting terhadap penurunan kadar $h s$ CRP. Antosianin diketahui dapat menekan proses inflamasi di dalam tubuh sehingga kadar $h s$ CRP pun dapat mengalami penurunan. ${ }^{17,39}$ ROS yang telah terbentuk akibat hiperglikemia dapat merusak membran sel yang menyebabkan inflamasi. Radikal bebas atau ROS menyerang membran dan merusak sel sehingga dibutuhkan sistem kekebalan untuk melindunginya. Antosianin yang dikonsumsi 
dapat berfungsi sebagai sistem kekebalan atau antioksidan dimana akan bekerja dengan melindungi lipid dari proses peroksidasi oleh radikal bebas. ${ }^{33}$ Cyanidin 3-glukosida yang terdapat di dalam antosianin dapat menangkap ROS dan memutus rantai serta menghambat terjadinya reaksi stress oksidatif akibat akumulasi ROS yang tinggi. ${ }^{39}$

Data menunjukkan bahwa kadar $h s$ CRP pada kelompok tikus P2 lebih rendah dibanding kelompok tikus P1. Hal ini terkait kadar antosianin yang lebih tinggi pada kelompok tikus P2 dengan homogenisasi nasi beras hitam ${ }^{40}$ dimana semakin gelap warna bahan pangan, maka semakin tinggi kandungan antosianin. ${ }^{13}$ Asupan antosianin yang semakin tinggi menyebabkan tingginya aktifitas antioksidan dalam perlindungan sel agar tidak mengalami inflamasi. ${ }^{41}$

Hasil pengukuran menunjukkan kadar $h s \mathrm{CRP}$ yang tergolong rendah pada semua kelompok dibandingkan dengan cut off point untuk resiko penyakit kardiovaskuler. Hal ini disebabkan inflamasi yang dialami oleh kelompok tikus masih bersifat akut, sementara penyakit kardiovaskuler bersifat kronis. Penelitian menunjukkan bahwa dengan nilai $h s \mathrm{CRP}>14,8 \mathrm{ng} / \mathrm{dl}$ sudah terdapat inflamasi di dalam tubuh tikus, ${ }^{42}$ sehingga ketiga kelompok perlakuan yang dikondisikan DM sudah mulai mengalami inflamasi.

Hal ini sejalan dengan penelitian tentang pemberian suplementasi pigmen beras hitam pada tikus dengan defisiensi apolipoprotein $E$ menunjukkan hasil bahwa pigmen beras hitam menghambat pembentukan plaque atherosklerosis, mengurangi stres oksidatif dan inflamasi, dimana antosianin memiliki sifat antiatherosklerosis yang mampu menurunkan lipid di dalam darah dan berfungsi sebagai antioksidan. ${ }^{43}$ Berdasarkan hal tersebut, dapat dikatakan bahwa hasil dari penelitian sejalan dengan teori yang ada.

\section{SIMPULAN}

Pemberian nasi beras merah dan nasi beras hitam menunjukkan adanya perbedaan kadar $h s$ CRP secara signifikan. Kadar $h s$ CRP paling rendah pada kelompok tikus dengan pemberian nasi beras hitam.

\section{SARAN}

Perlu dilakukan edukasi bahwa beras hitam lebih efektif dalam menurunkan kadar $h s$ CRP pada diabetesi dibandingkan beras merah yang dapat dikonsumsi dengan cara komplementasi beras hitam dengan jenis beras lain, serta perlu dilakukan penelitian lebih lanjut mengenai asupan antosianin pada manusia dari berbagai jenis pangan yang dikonsumsi untuk menekan kejadian inflamasi pada diabetesi.

\section{UCAPAN TERIMAKASIH}

Terimakasih peneliti sampaikan kepada pembimbing dan penguji atas bimbingan, saran dan evaluasinya yang membangun dalam penyusunan serta penulisan karya ilmiah ini, serta seluruh pihak yang telah berpartisipasi sehingga penelitian ini dapat terselesaikan.

\section{DAFTAR PUSTAKA}

1. WHO. Diabetes Mellitus [Internet]. [cited 2017 Jun 13].

2. Darmono. Pola Hidup Sehat Penderita Diabetes Melitus. In: Darmono, Suhartono T, Temayun TGD, Padmomartono FS, editors. Diabetes Melitus Ditinjau Dari Berbagai Penyakit Dalam. Semarang: Badan Penerbit Universitas Diponegoro; 2007. p. 15-30.

3. Franz M. Endocrine Disease. In: Medical Nutrition and Disease: a case-based approach. 5th ed. West Sussex: John Wiley \& Sons; 2014. p. 332-74.

4. Prasad KN. Micronutrients for the Prevention of Diabetes and Improvement of the Standard Therapy. In: Micronutrients in Health and Disease. USA: CRC Press; 2011. p. 79.

5. Webb GP. Dietary Supplements and Functional Foods. United Kingdom: Blackwell Publishing; 2005. p. 107-119.

6. Herminingsih S, Uddin I, Tanuwidjojo S. Patogenesis Penyakit Kardiovaskuler Pada Diabetes Melitus. In: Darmono, Suhartono T, Temayun TGD, Padmomartono FS, editors. Diabetes Melitus Ditinjau Dari Berbagai Penyakit Dalam. Semarang: Badan Penerbit Universitas Diponegoro; 2007. p. 245-56.

7. Yerizel E, Hendra P, Edward Z, Bachtiar H. Pengaruh Hiperglikemia Terhadap hsCRP Pada Penderita Diabetes Melitus Tipe 2. Pros Semin Ilm PBBMI. 2015;1-29.

8. Putri NE, Zakaria FR, Prangdimurti E. Pengaruh Intervensi Tahu Kedelai Hitam Kaya Serat Terhadap Glukosa Darah Dan Inflamasi Responden Diabetes Melitus Tipe 2. J Agric Technol. 2016;1:87-90.

9. Badan Pusat Statistik. Sensus Pertanian dan Pertambangan-Produksi Padi Menurut Provinsi (ton). 2015. p.1-10

10. Aryana I. Kandungan dan hasil antosianin galur padi beras merah pada tiga lingkungan tumbuh berbeda. Agroteksos. 2007;17:167-62.

11. Suliartini N, Sadimantara G, Muhidin WT. Pengujian Kadar Antosianin Padi Gogo Beras Merah Hasil Koleksi Plasma Nutfah Sulawesi Tenggara. Crop Agro. 2011;4 (2):43-8.

12. Suhartatik N, Karyantina M, Mustofa A, Cahyanto MN, Raharjo S, Rahayu ES. Stabilitas 
Ekstrak Antosianin Beras Ketan (Oryza sativa var. glutinosa) Hitam Selama Proses Pemanasan dan Penyimpanan. Agritech. 2013;33 (4):38490.

13. Maulida R, Guntarti A. Pengaruh Ukuran Partikel Beras Hitam (Oryza sativa L.) terhadap Rendemen Ekstrak dan Kandungan Total Antosianin. Pharmaciana. 2015;5 (1):9-16.

14. Indrasari SD, Wibowo P, Purwani E. Evaluasi Mutu Fisik, Mutu Giling, dan Kandungan Antosianin Kultivar Beras Merah. J Penelit Pertan Tanam Pangan. 2010;29 (1). 1-15

15. Suhartatik N, Cahyanto MN, Raharjo S, Rahayu ES. Aktivitas Antioksidan Beras Ketan Hitam Selama Fermentasi. J Teknol dan Ind Pangan. 2013;24 (1):115-9.

16. Craig winston J. Health-Promoting Phytochemicals: Beyond the Traditional Nutrients. In: Vegetarian Nutrition. United States of America: CRC Press; 2001. p. 340.

17. Kushwaha UK. Black Rice Research, History and Development. Nepal: Springer; 2016. p. 160-161.

18. Fernando B. Rice as a Source of Fibre. Rice Res. 2013;1(2):1-4.

19. Corwin EJ. Pankreas dan Diabetes Melitus. In: Buku Saku Patofisiologi. 3th ed. Jakarta: EGC; 2009. p. 633-42.

20. Bantle J, Wylie-Rosett J, Albright A, Apovian C, Clark N, Franz $M$ et all. Nutrition recommendations and interventions for diabetes: A position statement of the American Diabetes Association. Am Diabetes Assoc Diabetes Care. 2008:31.

21. Queiroz K, Silva I, Alfenas R. Influence of the glycemic index and glycemic load of the diet in the glycemic control of diabetic children and teenagers. Nutr Hosp. 2012;27(2):510-5.

22. Atkinson FF, Foster-Powell K, Brand-Miller JC. Glycemic Load Values. Diabetes Care. 2008;31:2281-3.

23. Buyken A, Toeller M, Heitkamp G, Karamanos B, Rottiers R, Muggeo M, et al. Glycemic index in the diet of European outpatients with type 1 diabetes: relations to glycated hemoglobin and serum lipids. Am J Clin Nutr. 2001;73(3):57481.

24. Levine TB, Levine AB. Inflammation. In: Metabolic Syndrome and Cardiovascular Disease. Second Edi. USA: Wiley Blackwell; 2013. p. 198.

25. Zhu L, Zou Y, Wang Y, Luo X, Sun K, Wang H, et al. Prognostic Significance of Plasma HighSensitivity C-Reactive Protein in Patients With Hypertrophic Cardiomyopathy. J Am Hear Assoc. 2017;6:2-7.
26. Menteri Kesehatan Republik Indonesia. Peraturan Menteri Kesehatan Republik Indonesia Nomor 75 Tahun 2013 tentang Angka Kecukupan Gizi yang Dianjurkan bagi Bangsa Indonesia. Jakarta; 2013. p. 1-10.

27. Li D, Zhang Y, Liu Y, Sun R, Xia M. Purified Anthocyanin Supplementation Reduces Dyslipidemia, Enhances Antioxidant Capacity and Prevents Insulin Resistance in Diabetic Patients. J Nutr Dis. 2015;145:742-8.

28. Chikezie P, Ojiako O, Ogbuji A. Oxidative Stress in Diabetes Mellitus. Integr Obes Diabetes. 2015;1(3):71-9.

29. Firdaus, Rimbawan, Marliyati SA, Roosita K. Model Tikus Diabetes Yang Diinduksi Streptozotocin Suksrosa Untuk Pendekatan Penelitian Diabetes Melitus Gestasional. J MKMI. 2016;12(1):29-34.

30. Ghasemi A, Khalifi S JS. Streptozotocinnicotinamide-induced rat model of type 2 diabetes (review). Acta Physiol Hung. 2014;101(4):408-20.

31. Granner DK. Hormon Pankreas dan Traktus Gastrointestinal. In: Murray RK, Granner DK, Rodwell VW, editors. Biokimia Harper. 25th Ed. Jakarta: EGC; 2003. p. 582-93.

32. Franz MJ. Medical Nutrition Therapy for Diabetes Mellitus and Hypoglycemia of Nondiabetic Origin. In: Mahan LK, EscottStump S RJ, editor. Krause's Food and Nutrition Care Process. 13th Ed. Elsevier Saunders; 2012. p. 792-834.

33. CLarkson P, Thompson H. Antioxidants: What Role They Play in Physical Activity and Health? Am J Clin Nutr. 2000;72:637S-46S.

34. Istiqomah A, Rustanti N. Indeks Glikemik, Beban Glikemik, Kadar Protein, Serat dan Tingkat Kesukaan Kue Kering Tepung Garut Dengan Substitusi Tepung Kacang Merah. J Nutr Coll. 2015;4(2):620-7.

35. Ettinger S. Macronutrients: Carbohidrates, Proteins and Lipids. In: Mahan LK, EscottStump S, editors. Krause's Food, Nutrition and Diet Therapy. 11th Ed. United States of America: Elsevier Saunders; 2004. p. 37-73.

36. Ma Y, Griffith JA, Chasan-Taber L, Olendzki BC, Jackson E, Stanek-III EJ, et al. Association between Dietary Fiber and Serum C-Reactive Protein. J Clin Nutr. 2006;83(4):760-6.

37. Darmono, Suhartono T, Pemayun TGD et all. Diabetes Melitus Ditinjau Dari Berbagai Aspek Penyakit Dalam. Semarang: Badan Penerbit Universitas Diponegoro; 2007. p. 15-16.

38. Hernawan E, Meylani V. Analisis Karakteristik Fisikokimia Beras Putih, Beras Merah dan Beras Hitam. J Kesehat Bakti Tunas Husada. 2016;15 
(1).

39. Lee Y-M, Yoon Y, Haelim-Yoon, Park H-M, Song S, Yeum K-J. Dietary Anthocyanins Against Obesity and Inflammation. Nutrients. 2017;9(10):1-15.

40. Basito. Kajian Substitusi Bekatul Beras Merah dan Beras Hitam Terhadap Sifat Sensoris dan Fisikokimia Pada Pembuatan Roti Tawar. J Teknol Has Pertan. 2012;5(2):24-31.

41. Khoo HE, Azlan A, Tang ST, Lim SM. Anthocyanidins and Anthocyanins: Colored Pigments as Food, Pharmaceutical Ingredients and The Potential Health Benefits. Food Nutr Res. 2017;61(1):1-21.
42. Shrestha K, Motoki H, W.Troughton R, G.Borowski A, L.Klein A, Tang W. W. Elevated Baseline High-Sensitive C-Reactive Protein Predicts Progressive Decline in Left Ventricular Myocardial Mechanics and Impaired Filling Rather Than Structural Remodeling in Chronic Systolic Heart Failure. Cardiovasc Psycology. 2013;19(8):S7.

43. Xia M, Ling WH, Ma J, Kitts DD, Zawistorski J. Supplementation of Diets with the Black Rice Pigment Fraction Attenuates Atherosclerotic Plaque Formation in Apolipoprotein E Deficient Mice. Am Soc Nutr Sci. 2003;133 (3):744-51. 